\title{
INTERNET FINANCIAL REPORTING: STUDI KOMPARASI BANK UMUM SYARIAH DI INDONESIA DAN MALAYSIA
}

\author{
Taqiyah Dinda Insani \\ Program Studi S1 Ekonomi Islam-Fakultas Ekonomi dan Bisnis-Universitas Airlangga \\ Email: tdindainsani@yahoo.com \\ Noven Suprayogi \\ Departemen Ekonomi Syariah-Fakultas Ekonomi dan Bisnis-Universitas Airlangga \\ Email: noven2005@gmail.com
}

\begin{abstract}
:
The purpose of this study was to determine the differences of Internet Financial Reporting Quality. This study was using quantitative approach with independent sample t test and mann whitney $u$ test. The population of this study was official website of islamic banks in Indonesia and Malaysia. determination of the number of samples using (sampling jenuh), where all of the population is used as a sampel. Data that being used was secondary data. The data was collected from official website of the sentral banks in each country. The result of this study showed that there was significant differences of Internet Fianncial Reporting Quality between Indonesia and Malaysia. The difference is caused there are significant differences between the quality of content and timeliness components. Meanwhile, there is no differences between technology and user support components
\end{abstract}

Keywords : Internet Financial Reporting, Content, Timeliness, Technology, User Support, Islamic Bank, Indonesia, Malaysia

\section{PENDAHULUAN}

Laporan keuangan menurut

Pernyataan Standar Akuntansi Keuangan nomor 1 tentang penyajian laporan kevangan, merupakan suatu penyajian terstuktur dari posisi keuangan dan kinerja keuangan suatu entitas sebagai bentuk pertanggung jawaban manajemen atas penggunaan sumber daya yang dipercayakan kepada mereka yang bertujuan memberikan informasi mengenai posisi keuangan, kinerja keuangan, dan arus kas entitas yang bermanfaat bagi sebagian besar pengguna laporan keuangan dalam pembuatan keputusan ekonomik. Selain itu, menurut Financial Accounting Standards Board (FASB) dalam Statement of Financial Concept (SFAC) nomor 1 penyajian informasi tersebut harus berguna bagi investor, kreditor dan pihak lainnya guna pembuatan keputusan investasi, pemberian kredit dan keputusan lainnya. Salah satunya adalah agar investor, kreditor dan pihak lain dapat menaksir jumlah, waktu dan ketidakpastian penerimaan vang dimasa mendatang (Suwardjono, 2005:157). Pengungkapan informasi yang dilakukan oleh perusahaan adalah untuk mengurangi asimetri informasi yang mungkin terjadi di antara manajemen dan stakeholdersnya, dan salah satu pengungkapan informasi yang dilakukan oleh perusahaan adalah melalui internet, yaitu melalui website pribadi (Larasati, 2012:4).

Pada awalnya penciptaan website ini hanya bertujuan untuk

\footnotetext{
1) Jurnal ini merupakan bagian dari skripsi yang ditulis oleh Taqiyah Dinda Insani, NIM: 041211432101 , yang diuji pada bulan April 2016
} 
Insani, et al/Jurnal Ekonomi Syariah Teori dan Terapan Vol. 3 No. 11 November 2016: 886-899; INTERNET FINANCIAL REPORTING: STUDI KOMPARASI BANK UMUM SYARIAH DI INDONESIA DAN MALAYSIA

memasarkan produk yang dihasilkan oleh perusahaan (Seetharaman dkk (2006) dalam Larasati, 2012:3). Namun seiring dengan berjalannya waktu, website bukan hanya digunakan untuk hal tersebut, melainkan juga sebagai media komunikasi dengan pihak-pihak terkait perusahaan, baik dengan shareholders, stakeholders, dan pihak lain yang berkepentingan. (Larasati, 2012:3).

Pengungkapan informasi menggunakan media internet disebut dengan Internet Financial Reporting/Corporate Internet Reporting/eReporting (Roso, 2012:22) yang dalam penelitian ini selanjutnya disebut dengan Internet Financial Reporting (IFR). Berdasarkan jenis pengungkapannya, IFR merupakan pengungkapan sukarela (voluntary disclosure), yaitu pengungkapan yang dilakukan perusahaan di luar apa yang diwajibkan oleh standar akuntansi atau peraturan badan pengawas (Suwardjono, 2005:583). Pengungkapan sukarela perusahaan menjadi penting karena hal tersebut bertujuan meningkatkan nilai perusahaan dan mengurangi risiko penilaian yang terlalu rendah oleh pasar (Agboola dan Salawu, 2012:96). Secara teoritis, investor secara umum memiliki persepsi bahwa ketiadaan pengungkapan sukarela sebagai indikasi "berita buruk" mengenai perusahaan (McKinnon dan Dalimunthe (1993) dalam Agboola dan Salawu, 2012:96). Beberapa manfaat pengungkapan sekarela menurut Almilia
(2008:119) adalah menghasilkan keputusan yang lebih baik bagi investor, memperbaiki akuntabilitas, dan memperbaiki prediksi risiko yang dilakukan oleh investor. Kemudian, pada penelitian mengenai dampak IFR terhadap harga saham, return saham, nilai perusahaan dan profitabilitas pada perusahaan manufaktur dan perbankan, diperoleh bahwa terdapat perbedaan harga saham dan profitabilitas antara perusahaan perbankan yang memiliki kualitas IFR tinggi dengan perusahaan perbankan yang memiliki kualitas IFR rendah. Perbedaan tersebut adalah semakin tinggi IFR perbankan semakin tinggi harga saham dan profitabilitasnya.

Saat ini telah terdapat lembaga yang melakukan penilaian atas kualitas website perusahaan dunia yaitu IR Global Rankings. Investor Relation Global Rankings juga memberikan penghargaan berkaitan dengan website perusahaan. Peringkat dibuat berdasarkan evaluasi teknis yang dilakukan oleh tim spesialis dan diverifikasi oleh komite independen. Penilaian tersebut mengacu pada tinjauan teknis (bukan jajak pendapat atau survey opini) yang didukung oleh ahli audit dan hukum. Perusahaan yang dinilai dan mendapatkan 30 peringkat teratas akan memiliki peninjauan eksternal dan dapat melakukan positioning hubungan investor serta upaya komunikasi keuangan di antara praktisi terbaik dari perusahaan terkemuka di seluruh dunia, selain itu 
Insani, et al/Jurnal Ekonomi Syariah Teori dan Terapan Vol. 3 No. 11 November 2016: 886-899; INTERNET FINANCIAL REPORTING: STUDI KOMPARASI BANK UMUM SYARIAH DI INDONESIA DAN MALAYSIA

perusahaan tersebut akan dipublikasikan sehingga memperluas jangkauannya.

. Salah satu industri yang memiliki kewajiban tinggi untuk melakukan pengungkapan informasi adalah industri perbankan, karena perbankan merupakan lembaga kepercayaan. Salah satu karakteristik khusus bank adalah sebagian sifat fisik asetnya tidak tampak, sedangkan aktiva berwujud nilainya relatif kecil, objek yang diperdagangkan pun bersifat abstrak (uang dan jasa) sehingga perlu adanya internal control yang ketat (Taswan, 2013:2). Taswan (2013:2-3) juga mengungkapkan keunikan bank, yaitu bank dapat bertindak sebagai asset transformer, bank bisa menerbitkan klaim keuangan berupa surat berharga obligasi dan deposito kemudian ditempatkan dalam bentuk kredit. Berdasarkan karakteristik dan keunikan bank, maka dapat dipastikan bahwa pengelolaan dan pengungkapan informasi untuk pengambilan keputusan sangat diperlukan.

Perbankan di dunia sedang berjalan dengan dua sistem, yaitu secara konvensional dan syariah. Perbankan syariah sebagai entitas syariah memiliki kewajiban melakukan pengungkapan informasi yang memadai bagi penggunanya, karena ia harus dioperasikan sesuai dengan prinsip-prinsip syariah. Al Quran secara tersirat menjelaskan tanggung jawab pelaporan kevangan dalam Surat An-Nisa ayat 58:

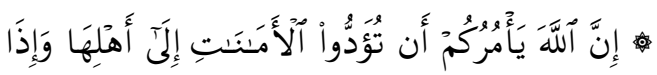

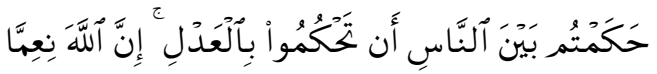

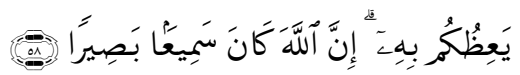

inna allāha ya'murukum an tuadduu al-amānāti ilā ahlihā waiżā hakamtum bayna annāsi an taḥkumū bil'adli inna allāha ni'immā ya'izukum bihi inna allāha kāna samīan bașirān

Artinya: Sesungguhnya Allah menyuruh kamu menyampaikan amanat kepada yang berhak menerimanya, dan (menyuruh kamu) apabila menetapkan hukum di antara manusia supaya kamu menetapkan dengan adil. Sesungguhnya Allah memberi pengajaran yang sebaik-baiknya kepadamu. Sesungguhnya Allah adalah Maha Mendengar lagi Maha Melihat.

Tafsir ayat tersebut menurut Ibnu Katsir (2001:251-261), bahwa amanat itu ialah semua hal yang mereka diperintahkan untuk melakukannya dan semua hal yang dilarang mereka mengerjakannya. Asimetri informasi terjadi ketika manajemen tidak secara penuh mengungkapkan informasi, sehingga manajer memiliki informasi yang lebih baik dibandingkan stakeholdersnya. Kemudian dijelaskan bahwa berbuat adil sehari lebih baik dari melakukan ibadah empat puluh tahun, dalam hal ini dengan menyamakan informasi yang dimiliki dalam upaya mengurangi asimetri informasi akan meningkatkan keadilan kedua belah pihak yang bersangkutan. Allah memerintahkan kepada manusia untuk menyampaikan amanat-amanat tersebut dan memutuskan hukum dengan adil diantara mereka serta lain-lainnya 
Insani, et al/Jurnal Ekonomi Syariah Teori dan Terapan Vol. 3 No. 11 November 2016: 886-899; INTERNET FINANCIAL REPORTING: STUDI KOMPARASI BANK UMUM SYARIAH DI INDONESIA DAN MALAYSIA

yang termasuk perintah-perintah dan syariat-syariat-Nya yang sempurna lagi agung dan mencakup semuanya. Oleh karena itu, penyembunyian informasi oleh manajemen atas stakeholdersnya dapat menyebabkan tindakan dzalim kepada salah satu pihak. Tindakan-tindakan menyimpang tersebut sangatlah bertentangan dengan perintah dan syariat-Nya. Lalu diakhir ayat ditegaskan bahwa Allah maha mendengar semua ucapan manusia lagi maha melihat semua perbuatan manusia. Oleh karena itu, manusia harus selalu merasa diawasi oleh Allah sehingga rasa takut tersebut dapat mengontrol tindakannya yang mungkin dilandasi nafsu dan ditunggangi setan.

Perbankan syariah dunia saat ini memiliki enam negara pemain besar, yakni Qatar, Indonesia, Saudi Arabia, Malaysia, UAE dan Turki yang lebih dikenal dengan sebutan QISMUT (World Islamic Banking Competitiveness Report, 20132014). Indonesia dan Malaysia merupakan dua negara yang sama-sama berasal dari ASEAN, perkembangan yang terjadi di bidang perbankan syariah dari keduanya menjadi daya tarik untuk dikomparasikan. Selain itu, Indonesia dan Malaysia memiliki akar budaya yang sama, dan secara geografis keduanya berada pada posisi yang berdekatan.

Indonesia dan Malaysia dari sisi perkembangan IFRnya, keduanya memiliki perkembangan internet yang serupa. Perkembangan internet dunia disambut baik oleh kedua negara, dengan pemanfaatan jaringan tersebut. Pada tahun 1994, di Indonesia mulai beroperasi ISP (Internet Service Provider) komersial pertama, yaitu IndoNET (Hidayat,2011:3). Sejak saat itu perusahaan mulai menggunakan Internet secara maksimal untuk kepentingannya dan para stakeholdernya. Pada tahun yang sama, di Malaysia juga mengalami perkembangan penggunaan jaringan internet dengan jumlah 254 perusahaan yang menggunakan internet untuk kepentingan usahanya (majalahsains.com). Penggunaan Internet tersebut juga berangsur-angsur digunakan untuk penyampaian laporan keuangan guna pemaksimalan efektifitas dan efisiensi.

Internet Financial Reporting sendiri sebenarnya tidak terstandarisasi, sehingga penerapannya pada setiap perusahaan berbeda. Beberapa penelitian sebelumnya telah ada yang membahas mengenai IFR pada perbankan. Salah satunya, penelitian tentang perbandingan IFR pada perbankan yang go publik di Indonesia dan Malaysia yang dilakukan oleh Hendy Apriyanto. Hasil penelitian tersebut adalah tidak terdapat perbedaaan di antara keduanya. Penelitian lainnya tentang perbandingan IFR perbankan yang go publik di Indonesia dan Singapura, yang dilakukan oleh Azizul Khakim, diperoleh bahwa terdapat perbedaan di antara keduanya, khususnya pada komponen 
Insani, et al/Jurnal Ekonomi Syariah Teori dan Terapan Vol. 3 No. 11 November 2016: 886-899; INTERNET FINANCIAL REPORTING: STUDI KOMPARASI BANK UMUM SYARIAH DI INDONESIA DAN MALAYSIA

ketepatwaktuan/timeliness, pemanfaatan teknologi/technology dan dukungan pengguna/user support.

Semakin tinggi Internet Financial Reporting suatu Bank Umum Syariah, akan semakin menurunkan asimetri informasi yang terjadi dintara para pihak yang berkepentingan. Menurunnya asimetri informasi tersebut akan meningkatkan kepercayaan para pemangku kepentingan kepada manajemen Bank Umum Syariah. Oleh sebab itu, penelitian mengenai analisis perbandingan kualitas internet financial reporting Bank Umum Syariah di Indonesia dan Malaysia menjadi menarik untuk dilakukan.

Berdasarkan Uraian latar belakang yang ada maka permasalahan penelitian ini dapat dirumuskan sebagai berikut: 1. Apakah terdapat perbedaan yang signifikan pada kualitas IFR antara Bank Umum Syariah di Indonesia dan Malaysia?

2. Apakah terdapat perbedaan yang signifikan pada kualitas komponen isi/content antara Bank Umum Syariah di Indonesia dan Malaysia? 3. Apakah terdapat perbedaan yang signifikan pada kualitas komponen ketepatwaktuan/timeliness antara Bank Umum Syariah di Indonesia dan Malaysia? 4. Apakah terdapat perbedaan yang signifikan pada kualitas komponen pemanfaatan teknologi/technology antara Bank Umum Syariah di Indonesia dan Malaysia? 5. Apakah terdapat perbedaan yang signifikan pada kualitas komponen dukungan pengguna/user support antara Bank Umum Syariah di Indonesia dan Malaysia?

Adapun tujuan dari penelitian ini adalah untuk mengetahui apakah diantara Bank Umum Syariah di Indonesia dan Malaysia terdapat perbedaan yang signifikan pada kualitas: 1. IFR, 2. komponen isi/content, 3. komponen ketepatwaktuan/timeliness, 4. komponen pemanfaatan teknologi/technology, 5. komponen dukungan pengguna/user support.

\section{LANDASAN TEORI}

Penelitian ini menggunakan teori keagenan dan sinyal. Teori keagenan bersumber dari adanya hubungan keagenan. Jensen dan Meckling (1976:308) menjelaskan bahwa hubungan keagenan adalah kontrak di mana satu orang atau lebih (principal) melibatkan orang lain (agen) untuk melakukan sejumlah jasa atas nama mereka (principal) serta mendelegasikan beberapa wewenang pengambilan keputusan kepada agen. Akibat pendelegasian wewenang oleh pemilik perusahaan untuk pembuatan keputusan, maka akan memicu timbulnya konflik atas kepentingan yang disebut teori keagenan (Brigham dan Houston,2001:22). Pada pembahasan manajemen keuangan, hubungan keagenan terdiri dari hubungan antara pemegang saham dan manajer, serta hubungan antara pemegang saham (melalui manajer) dan kreditor (Jensen dan Meckling (1976) 
Insani, et al/Jurnal Ekonomi Syariah Teori dan Terapan Vol. 3 No. 11 November 2016: 886-899; INTERNET FINANCIAL REPORTING: STUDI KOMPARASI BANK UMUM SYARIAH DI INDONESIA DAN MALAYSIA

dalam Brigham dan Houston,2001:22). Peran agen oleh manajemen tentu menyebabkannya memiliki informasi yang lebih baik mengenai kondisi internal perusahaan dibandingkan para stakeholdernya. Keadaan tersebut disebut dengan asimetri informasi, yaitu ketidakseimbangan informasi mengenai suatu kondisi tertentu. Asimetri informasi tersebut memicu timbulnya agency problem yang menyebabkan agency cost. Oleh karena itu laporan keuangan yang merupakan wajah perusahaan dapat menjadi media bagi stakeholder untuk menilai kinerja manajemen. Internet Financial Reporting adalah salah satu sarana manajemen untuk mengomunikasikan kinerjanya kepada stakeholdernya secara ekonomis dan efisien. Internet Financial Reporting sebagai penyampaian laporan keuangan dapat mengurangi biaya keagenan akibat adanya agency problem, karena dapat menjadi alat untuk mengurangi asimetri informasi.

Sinyal (Signal) adalah suatu tindakan yang diambil oleh manajemen suatu perusahaan yang memberikan petunjuk kepada investor tentang bagaimana menajemen melihat prospek perusahaan (Brigham dan Houston,2011:214). Teori sinyal berkembang akibat adanya kondisi asimetri informasi. Bagaimana seharusnya perusahaan memberikan sinyal kepada stakeholdernya disebut teori sinyal. Penyampaian laporan keuangan dapat dianggap sebagai sinyal perusahaan kepada stakeholdernya apakah manajemen telah berbuat sesuai dengan kontrak atau belum (yeye, 2011: 21). Laporan keuangan harus memiliki informasi yang berguna bagi stakehodernya, terutama pemilik dan kreditor, karena keduanya berada pada kondisi ketidakpastian paling tinggi akibat kinerja manajemen.

Pada dasarnya dalam ilmu manajemen, laporan keuangan dimanfaatkan perusahaan untuk memberikan sinyal positif maupun negatif kepada pemakainya (Sulistyanto, 2008: 65). Sinyal positif adalah suatu tindakan yang dilakukan oleh manajemen yang berdampak pada respon positif oleh stakeholder sehingga menguntungkan bagi manajemen, sedangkan sinyal negatif adalah suatu tindakan yang dilakukan oleh manajemen yang berdampak pada respon negatif oleh stakeholder sehingga merugikan bagi manajemen. Pada pembahasan teori sinyal, setiap tindakan mengandung informasi, terjemahan informasi inilah yang digunakan stakeholder sebagai acuan dalam merespon tindakan manajemen.

Keberadaan Internet Financial Reporting, sebagai pengungkapan sukarela, dapat meningkatkan nilai perusahaan (Agboola dan Salawu, 2012:96). Tindakan manajemen menyediakan IFR yang berkualitas sebagai sinyal kepada stakeholdernya dapat menguntungkan perusahaan, 
Insani, et al/Jurnal Ekonomi Syariah Teori dan Terapan Vol. 3 No. 11 November 2016: 886-899; INTERNET FINANCIAL REPORTING: STUDI KOMPARASI BANK UMUM SYARIAH DI INDONESIA DAN MALAYSIA

dengan kata lain tindakan tersebut dapat menjadi sinyal positif. Sedangkan, ketiadaannya dapat menjadi indikasi berita buruk mengenai perusahaan (McKinnon dan Dalimunthe (1993) dalam Agboola dan Salawu, 2012:96). Oleh karena itu, tindakan manajemen tidak menyediakan IFR yang berkualitas dapat merugikan perusahaan, dengan kata lain tindakan tersebut dapat menjadi sinyal negatif.

Berdasarkan teori sinyal, sinyalsinyal berupa keberhasilan atau kegagalan harus dapat disampaikan oleh manajemen kepada principal dengan baik agar senantiasa dapat memberikan keuantungan bagi kedua belah pihak (yeye, 2011: 21). Pada penelitian ini, teori sinyal menjadi landasan dalam hubungan kinerja keuangan dan praktik IFR di Bank Umum Syariah.

Teori lain yang digunakan dalam penelitian ini adalah laporan keuangan syariah. Berdasarkan PSAK Syariah No.101 tentang penyajian laporan kevangan syariah, laporan keuangan adalah suatu penyajian terstruktur dari posisi keuangan dan kinerja keuangan suatu entitas syariah. Tujuannya adalah untuk memberikan informasi mengenai posisi keuangan, kinerja keuangan, dan arus kas entitas syariah yang bermanfaat bagi sebagian besar pengguna laporan keuangan dalam membuat keputusan ekonomik. Laporan keuangan juga menunjukkan hasil pertanggungjawaban manajemen atas penggunaan sumber daya yang dipercayakan kepada mereka. Dalam rangka mencapai tujuan tersebut, laporan keuangan menyajikan informasi mengenai entitas syariah.

Salah satu media yang paling efektif dan efisien dalam penyampaian laporan kevangan adalah internet melalui website pribadi Bank Umum Syariah. Terdapat beberapa motif perusahaan untuk menyajikan informasi melalui internet. The Steering Committee of the Bank Umum Syariahiness Reporting Research Project (FASB, 2000) dalam Febrian (2010:39-40) menyebutkan motif tersebut antara lain adalah mengurangi biaya cetak dan posting laporan tahunan (annual report), akses yang lebih luas daripada praktek tradisional, memberikan informasi yang terkini, mempercepat waktu dalam distrbusi informasi, menjalin komunikasi dengan konsumen yang tidak teridentifikasi sebelumnya, menambah praktek pengungkapan tradisional, meningkatkan jumlah dan data yang diungkapkan, memperbaiki akses pada investor potensial untuk perusahaan kecil. Motif tersebut diharapkan dapat memberikan manfaat serupa bagi perusahaan.

Cara menilai kualtas IFR suatu website adalah dengan menggunakan indeks IFR yang dikembangkan oleh Cheng et. al. (2000) dalam Almilia (2008: 122) dan Larasati (2012:40). Indeks tersebut menilai enpat komponen IFR yaitu

isi/content, ketepatwaktuan/timeline, pemanfaatan 
Insani, et al/Jurnal Ekonomi Syariah Teori dan Terapan Vol. 3 No. 11 November 2016: 886-899; INTERNET FINANCIAL REPORTING: STUDI KOMPARASI BANK UMUM SYARIAH DI INDONESIA DAN MALAYSIA

teknologi/technology dan dukungan pengguna/user support. Isi/Content yang dimaksud dalam penelitian ini adalah isi website yang dinilai dari kelengkapan laporan keuangan yang disajikan serta bahasa yang digunakan. Ketepatwaktuan/Timeliness yang dimaksud dalam penelitian ini adalah kebaruan informasi yang disajikan dalam website.

Pemanfaatan Teknologi/Technology yang dimaksud dalam penelitian ini adlaah jumlah pemanfaatan teknologi yang digunakan pada website. Dukungan Pengguna/User yang dimaksud dalam penelitian ini adlaah keberagaman fasilitas yang disediakan dalam website untuk mendukung keberagaman penggunanya.

\section{METODE PENELITIAN}

Jenis data dalam penelitian ini adalah sekunder karena data tersebut diperoleh secara tidak langsung melalui media perantara (Indriantoro dan Supomo, 2011:147). Sumber data sampel penelitian ini didapat dari website resmi bank sentral masing-masing negara (Indonesia dan Malaysia) yakni www.bi.go.id dan www.bnm.gov.my, dan website resmi masing-masing bank syariah di kedua negara tersebut.

Peneliti memutuskan populasi yang digunakan dalam penelitian ini adalah website Bank Umum Syariah di kedua negara (Indonesia dan Malaysia). Pemilihan populasi tersebut karena Bank Umum Syariah berdiri secara mandiri sehingga memiliki kewenangan penuh untuk memutuskan pelaporan keuangan yang akan dilakukan. Berdasarkan data yang tersedia, teknik sampel yang digunakan dalam penelitian ini adalah sampling jenuh, sehingga semua populasi dijadikan sampel.

Langkah pertama yang dilakukan dalam menganalsis data untuk menguji hipotesis adalah menilai indeks IFR sampel penelitian. Lalu dilakukan uji normalitas untuk menentukan pengujian hipotesis yang akan digunakan. Apabila data berasal dari populasi yang terdistrii normal maka menggunakan uji hipotesis independent sample t test, apabila data berasal dari populasi yang tidak terdistribusi normal maka menggunakan uji hipotesis mann whitney u test. Setelah diuji menggunakan pengujian hipotesis yang sesuai, lalu dilakukan analisis hasil pengujian. Lalu, langkah terakhir adalah mencari penyebab dari hasil uji hipotesis tersebut.

\section{HASIL DAN PEMBAHASAN}

Berdasarkan hasil uji normalitas seperti pada tabel 1 didapatkan bahwa pada tingkat signifikansi 0.05 komponen timeliness Malaysia datanya tidak terdistribusi normal. Maka untuk IFR, komponen content, technology, dan user suport menggunakan uji hipotesis independent sample $\dagger$ test, sedangkan untuk komponen timeliness menggunakan uji hipotesis mann whitney $u$ test karena tingkat signifikansinya dibawah 0.05 
Insani, et al/Jurnal Ekonomi Syariah Teori dan Terapan Vol. 3 No. 11 November 2016: 886-899; INTERNET FINANCIAL REPORTING: STUDI KOMPARASI BANK UMUM SYARIAH DI INDONESIA DAN MALAYSIA

Tabel 1.

Hasil Uji Normalitas

\begin{tabular}{|l|l|l|}
\hline \multirow{2}{*}{ IFR } & $\begin{array}{l}\text { Kelompok } \\
\text { BUS }\end{array}$ & Signifikansi \\
\hline \multirow{3}{*}{ Content } & Indonesia & 0.935 \\
\cline { 2 - 3 } & Malaysia & 0.532 \\
\hline \multirow{3}{*}{ Timeliness } & Indonesia & 0.867 \\
\cline { 2 - 3 } & Malaysia & 0.998 \\
\cline { 2 - 3 } & Indonesia & 0.356 \\
\hline User Support & Indaysia & 0.019 \\
\cline { 2 - 3 } & Indonesia & 0.580 \\
\cline { 2 - 3 } & Malaysia & 0.525 \\
\hline
\end{tabular}

Sumber: Hasil Perhitungan Uji Normalitas dengan SPSS 17

Setelah dilakukan pengujian hipotesis untuk mengetahui apakah terdapat perbedaan yang signifikan atau tidak pada kualitas pelaporan keuangan menggunakan internet didapatkan hasil sebagai berikut:

Tabel 2.

Hasil Uji Hipotesis

\begin{tabular}{|l|l|}
\hline & Sig \\
\hline IFR & 0.009 \\
\hline Content & 0.011 \\
\hline Timeliness & 0.018 \\
\hline Technology & 0.724 \\
\hline User Support & 0.269 \\
\hline
\end{tabular}

Sumber: Sumber: Hasil Perhitungan Uji independent sample $t$ test dan mann whitney $u$ test dengan SPSS 17

Hasil pengujian tersebut dapat disimpulkan bahwa terdapat perbedaan yang signifikan antara Bank Umum Syariah di Indonesia dan Malaysia pada kualitas IFR, komponen content, dan timeliness, karena tingkat signifikansinya dibawah 0.05. untuk mengetahui bentuk perbedaannnya dapat dilihat pada ratarata komponen yang bersangkutan antara kedua negara tersebut. Karena rata-rata Indonesia lebih tinggi dibandingkan dengan rata-rata malaysia, maka dapat disimpulkan bahwa kualitas IFR Bank Umum Syariah indoneisa lebih baik dibandingkan dengan malaysua. Hal tersebut terjadi karena tingkat CAGR (Compound Annual Growth rate Indoensia lebih tinggi dibandingkan Malaysia. Indonesia memiliki CAGR sebesar 29\%, sedangkan CAGR Malaysia sebesar 17\%. Bedasarkan teori sinyal, Compound Annual Growth Rate sebagai suatu bentuk pertumbuhan merupakan sinyal positif yang akan mendorong Bank Umum Syariah di Indonesia untuk melakukan pelaporan keuangan secara maksimal, lebih dari dorongan yang dirasakan oleh Bank Umum Syariah di Malaysia, karena tingkat CAGR tersebut merupakan informasi positif yang nantinya akan diharapkan oleh Bank Umum Syariah dapat menghasilkan respon positif dari para stakeholdernya

Selain itu terkait dengan regulasi di kedua negara tentang penyampaian laporan keuangan pada Bank sentral, Indonesia dan malaysia masing-masing memilikinya. Namun peraturan di Indonesia seperti dimuat dalam PBI no 14 tahun 2012 terdapat sanksi atas 
Insani, et al/Jurnal Ekonomi Syariah Teori dan Terapan Vol. 3 No. 11 November 2016: 886-899; INTERNET FINANCIAL REPORTING: STUDI KOMPARASI BANK UMUM SYARIAH DI INDONESIA DAN MALAYSIA

pelanggarannya. Keterlambatan akan diberi sanksi membayar sejumlah rupiah, dengan ketentuan semakin panjang masa keterlambatan, maka sakan emakin besar sanksi yang akan diterima. Oleh karena itu dorongan untuk memberikan laporan keuangan secra memadai dan tepat waktu yang dirasakan oleh Bank Umum Syariah di Indoensia menjadi lebih bear dibandingkan dengan yang dirasakan okleh Bank Umum Syariah.

Hasil pengukuran kualitas Internet Financial Reporting tersebut juga dapat diartikan bahwa Bank Umum Syariah Indonesia dari sisi transparansi, memiliki kualitas yang lebih baik dibandingkan Malaysia. Islamic Financial Services Board (IFSB) dalam prinsip tata kelola perusahaan bagi bank syariah menyebutkan bahwa bank syariah harus melakukan pengungkapan yang memadai dan tepat waktu kepada pemegang akun investasi serta kepada publik (Greuning dan Zamir,2011:190). Ditinjau dari sisi transparansi tersebut, content IFR, yang manilai kelengkapan informasi yang disajikan, Bank Umum Syariah Indonesia lebih tinggi kualitasnya dibandingkan Bank Umum Syariah di Malaysia. Jadi dapat disimpulkan bahwa Bank Umum Syariah Indonesia mengungkapkan informasi yang lebih memadai bagi stakeholdernya. Kemudian jika ditinjau dari sisi timeliness IFR, yang menilai kebaruan informasi yang disajikan, Bank Umum Syariah Indonesia juga memiliki kualitas yang lebih baik dibandingkan dengan Bank Umum Syariah Malaysia.

Kualitas Internet Financial
Reporting menjadi penting karena bukan hanya tingginya tingkat kepentingan informasi bagi para stakeholder Bank Umum Syariah, namun karena kualitas tersebut mengindikasikan seberapa besar tanggung jawab Bank Umum Syariah dalam melakukan publikasi laporan keuangan melalui internet. Pada kasus entitas syariah, hal ini terkait erat dengan prinsip trasparansi.

Transparansi

menjadi pertimbangan penting bagi operasional Bank Umum Syariah karena pertimbangan syariat. Transparansi yang merupakan salah satu wujud implementasi amanah yang diwajibkan oleh Al Quran dalam surat An Nisa ayat 58, Bank Umum Syariah di Indonesia memiliki kualitas yang lebih baik dibandingkan Bank Umum Syariah di Malaysia.

Transparansi

mampu meningkatkan fungsi bank dan menyelamatkan kepentingan stakeholder jika semua pihak yang berkepentingan mempunyai akses yang cukup terhadap kegiatan usaha Bank Umum Syariah. Hal tersebut karena informasi memungkinkan bagi para deposan untuk mempertahankan atau menarik dananya dari bank yang bersangkutan (Chapra dan Habib,2008:86). Bank Umum Syariah Indonesia dalam upaya untuk meningkatkan transparansi dengan pemanfaatan pengguanakn media 
Insani, et al/Jurnal Ekonomi Syariah Teori dan Terapan Vol. 3 No. 11 November 2016: 886-899; INTERNET FINANCIAL REPORTING: STUDI KOMPARASI BANK UMUM SYARIAH DI INDONESIA DAN MALAYSIA

internet untuk pelaporan keuangannya lebih maksimal dibandingkan dengan Bank Umum Syariah Malaysia.

Chapra dan Habib (2008:87) juga menjelaskan atas dasar tersebutlah, transparansi merupakan faktor yang paling penting bagi semua pelaku pasar. Terlebih jika pelaku pasar yang menggunakan mekanisme profit and loss sharing, dimana deposan yang menanamkan investasinya memiliki potensi untuk menanggung risiko kerugian. Dengan demikian, deposan sangat membutuhkan informasi yang terkait dengan kinerja bank, sehingga ia dapat menentukan wahana investasi pada bank yang memiliki kinerja yang lebih baik. Bank Umum Syariah merupakan industri yang menggunakan mekanisme profit and loss sharing, oleh karena itu upaya untuk memaksimalkan pelaporan keuangan dan penggunaan sarana agar dapat menjangkau deposan harus senantiasa ditingkatkan.

Tabel 3.

Rata-rata Kualitas Bank Umum Syariah di Indonesia dan Malaysia

\begin{tabular}{|l|l|l|}
\hline & $\begin{array}{l}\text { Mean } \\
\text { Indonesia }\end{array}$ & $\begin{array}{l}\text { Mean } \\
\text { Malaysia }\end{array}$ \\
\hline IFR & 50.1250 & 43.7059 \\
\hline Content & 29.1250 & 25.2941 \\
\hline Timeliness & 4.6667 & 3.7059 \\
\hline Technology & 5.8333 & 5.4118 \\
\hline $\begin{array}{l}\text { User } \\
\text { Support }\end{array}$ & 10.5000 & 9.2941 \\
\hline
\end{tabular}

Sumber: Hasil Uji Analisis Deskriptif Bank Umum Syariah di Indonesia dan Malaysia dengan SPS 17

Sedangkan Pada komponen technology dan user support terdapat perbedaan yang tidaj sigifikan dantara keduanya. Karena tingkat signifikansinya lebih besar dari pada 0.05 .

Hal tersebut disebabkan karena sebagian besar Bank Umum Syariah di kedua negara tersebut bukan merupakan perusahaan yang go public. Perusahaan yang go public kepemilikan sahamnya memiliki potensi lebih besar dimiliki oleh orang di seluruh dunia, sehingga pemanfaatan pelaporan kevangan melalui internet/ Internet Financial Reporting akan lebih besar. Oleh karena itu pemanfaatna teknologi yang merupakan keunggulan pelaporan melalui internet dibandingkan pelaporan berbasis kertas harus dimaksimalkan. Keunggulan tersebut tercermin dari pemanfaatan teknologi yang digunakan pada website. Selain itu potensi luasnya stakeholder dapat memicu semakin beragamnya pengguna. Oleh karena itu ketersediaan fasilitas yang disediakan dalam website untuk mendukung keberagaman penggunanya menjadi penting untuk dilakukan.

Namun jika ditelaanh lebih dalam, meskipun perbedaan anatar komponen technoloigy dan user support anatar Bank Umum Syariah di Indonesia dan Malaysia tidak signifikan, namun dari segi kualitas indonesia lebih baik kualitas nya 
Insani, et al/Jurnal Ekonomi Syariah Teori dan Terapan Vol. 3 No. 11 November 2016: 886-899; INTERNET FINANCIAL REPORTING: STUDI KOMPARASI BANK UMUM SYARIAH DI INDONESIA DAN MALAYSIA

dibandingkand engan malaysia, karena nilai rata-ratanya lebih tunggi dibandingkan dengan malaysia.

Sehingga dapat disimpulkan bahwa bukan hanya pada komponen content IFR dan timeliness IFR indonesia memiliki keunggulan dalam kualitas pengungkapan melalui internet, melainkan juga pada komponen technology IFR dan user support IFR. Secara keseluruhan upaya Bank Umum Syariah di Indoensia untuk mengurangi asimetri informasi dengan pemberian sinyal berupa pelaporan keuangan melalui internet lebih baik dibandingkan Bank Umum Syariah di Malaysia.

\section{v. SIMPULAN}

Berdasarkan hasil analisis dan interpretasi data, maka dapat disimpulkan bahwa:

1. Terdapat perbedaan yang signifikan pada kualitas Internet Financial Reporting antara Bank Umum Syariah di Indonesia dan Malaysia pada tingkat signifikansi 0.05 .

2. Terdapat perbedaan yang signifikan pada kualitas komponen Isi/Content IFR antara Bank Umum Syariah di Indonesia dan Malaysia pada tingkat signifikansi 0.05 .

3. Terdapat perbedaan yang signifikan pada kualitas komponen ketepatwaktuan/Timeliness IFR antara Bank Umum Syariah di Indonesia dan Malaysia pada tingkat signifikansi 0.05 .
4. Terdapat perbedaan yang tidak signifikan pada kualitas komponen pemanfaatan teknologi/ technology IFR antara Bank Umum Syariah di Indonesia dan Malaysia pada tingkat signifikansi 0.05.

5. Terdapat perbedaan yang signifikan pada kualitas komponen dukungan pengguna/user support IFR antara Bank Umum Syariah di Indonesia dan Malaysia pada tingkat signifikansi 0.05 .

Secara keseluruhan, berdasarkan pengujian hipotesis, Bank Umum Syariah di Indonesia lebih baik dalam pengungkapan laporan keuangan menggunakan media internet.

\section{DAFTAR PUSTAKA}

Agboola, Ayodeji Akinlolu \& Mary Kehinde Salawu. 2012. The Determinants of Internet Financial Reporting: Empirical Evidence from Nigeria. Research Journal of Finance and Accounting, (Online), (http://iiste.org/, diakses 17 Desember 2015). Vol. 3. No. 11. 95-106. Almilia, Luciana Spica. 2008. Faktor-faktor yang Mempengaruhi Pengungkapan Sukarela "Internet Financial and Sustainability Reporting" . Jurnal Akuntansi \& Auditing Indonesia, (Online),

(http://digilib.mercubuana.ac.id/, diakses 17 Desember 2015). Vol. 12. No. 2. 117-131.

Anshori, Muslich \& Sri Iswati. 2009. Buku Ajar Metodologi Penelitian Kuantitatif. Surabaya: AUP 
Insani, et al/Jurnal Ekonomi Syariah Teori dan Terapan Vol. 3 No. 11 November 2016: 886-899; INTERNET FINANCIAL REPORTING: STUDI KOMPARASI BANK UMUM SYARIAH DI INDONESIA DAN MALAYSIA

Apriyanto, Hendy. 2014. Analisis Perbandingan Internet Financial Reporting pada Perbankan yang Go Publik di Indonesia dan Perbankan yang Go Publik di Malaysia. Skripsi Tidak Diterbitkan. Surabaya. STIE Perbanas

Brigham, Eugene F. \& Joel F. Houston. Tanpa Tahun. Manajemen Keuangan. Jilid 1. Edisi 8. Terjemahan oleh Dodo Suharto dan Herman Wibowo. 2001. Jakarta: Erlangga.

-----. Tanpa Tahun. Dasar-dasar Manajemen Keuangan. Jilid 2. Edisi 11. Terjemahan oleh Ali Akbar Yulianto. 2011. Jakarta: Salemba Empat.

Chapra, M. Umer \& Habib Ahmed. Corporate Governance Lembaga Kevangan Syariah. Terjemahan oleh Ikhwan A. Basri. 2008. Jakarta: Bumi Aksara

Febrian Hargyantoro.2010. Pengaruh Internet Financial Reporting Dan Tingkat Pengungkapan Informasi Website Terhadap Frekuensi Perdagangan Saham Perusahaan. Skripsi Tidak Diterbitkan. Semarang. Universitas Diponegoro

Ghozali, Imam. 2013. Aplikasi Analisis Multivariate dengan Program IBM SPSS 21 Update PLS Regresi. Edisi 7. Semarang: Badan Penerbit Universitas Diponegoro.

Greuning, Hennie Van \& Zamir lqbal. Analisis Risiko Perbankan Syariah. Terjemahan oleh Yulianti Abbas. 2011. Jakarta: Salemba Empat
Handayani, Emma \& Luciana Spica Almilia. 2013. Internet Financial Reporting: Studi Komparasi Perusahaan Manufaktur yang Terdaftar di Bursa Efek Indonesia dan Bursa Efek Malaysia. Jurnal Bisnis dan Ekonomi,(Online), (http://www.unisbank.ac.id/, diakses 17 Desember 2015). Vol. 20. No. 2. 100-112. Hidayat,Rudi. 2011. Teknologi Informasi Komunikasi. Jakarta: Erlangga

IAl. 2009. Pernyataan Standar Akuntansi Kevangan. Jakarta: Dewan Standar Akuntansi Keuangan IAI.

-. 2014. Standar Akuntansi Keuangan. Jakarta: Dewan Standar Akuntansi Keuangan IAI.

Indriantoro, Nur \& Bambang Supomo. 2011. Metodologi Penelitian Bisnis Untuk Akuntansi dan Manajemen. Edisi 1. Yogyakarta: BPFE

Jensen, Michael C. \& William H. Meckling. 1976. Theory of The Firm: Managerial Behaviour, Agency Cost and Ownership Structure. Journal of Financial Economics 3, (Online), (http://www.sciencedirect.com/, diakses 17 Desember 2015). 305-360.

Katsir, Ibnu. Tanpa Tahun. Tafsir Ibnu Katsir Juz 5. Terjemahan oleh Bahrun Abu Bakar. 2001. Bandung: Sinar Baru Algensindo.

-----. Tanpa Tahun. Tafsir Ibnu Katsir Juz 18. Terjemahan oleh Bahrun Abu Bakar. 2004. Bandung: Sinar Baru Algensindo.

Khakim, M. Azizul. 2015. Analisis Perbandingan Internet Financial Reporting pada Sektor Perbankan yang 
Insani, et al/Jurnal Ekonomi Syariah Teori dan Terapan Vol. 3 No. 11 November 2016: 886-899; INTERNET FINANCIAL REPORTING: STUDI KOMPARASI BANK UMUM SYARIAH DI INDONESIA DAN MALAYSIA

go Publik di Indonesia dan Singapura. Skripsi Tidak Diterbitkan. Surabaya. STIE Perbanas

Larasati, Noeke Dwi. 2012. Variabelvariabel yang Mempengaruhi Internet Financial Reporting. Skripsi Tidak Diterbitkan. Surabaya. Fakultas Ekonomi dan Bisnis. Universitas Airlangga.

Munir. 2013. Multimedia Konsep \& Aplikasi dalam Pendidikan. Bandung: Alfabeta.

Nuraini. 2015. Dampak Internet Financial Reporting terhadap Harga Saham, Return Saham, Nilai Perusahaan dan Profitabilitas pada Perusahaan manufaktur dan Perbankan. Skripsi Tidak Diterbitkan. Surabaya. STIE Perbanas

Roso, Wahyu Sejati. 2012. Pengaruh Karakteristik GCG terhadap Praktik Corporate Internet Reporting pada Perusahaan yang Terdaftar di BEI Tahun 2012. Skripsi Tidak Diterbitkan. Surabaya. Fakultas Ekonomi dan Bisnis. Universitas Airlangga.

Sulistyanto, H.Sri. 2008. Manajemen Laba Teori dan Model Empiris. Jakarta: Grasindo

Susilowati, Yeye dan Tri Turyanto. 2011. Reaksi Signal Rasio Profitabilitas dan Rasio Solvabilitas terhadap Return Saham Perusahaan. Dinamika Keuangan dan Perbankan, (Online), (http://www.unisbank.ac.id/, diakses 22 Desember 2015). Vol. 3. No. 1. 12-37.

Suwardjono. 2005. Teori Akuntansi Perekayasaan Pelaporan Kevangan. Edidi 3. Yogyakarta: BPFE-Yogyakarta
Taswan. 2013. Akuntansi Perbankan Transaksi dalam Valuta Rupiah. Edisi 3. Yogyakarta: UPP STIM YKPN.

www.ey.com

www.bi.go.id

www.bnm.gov.my

www.irglobalrankings.com

www.majalahsains.com 